\title{
MICROSTRUCTURE AND MECHANICAL PROPERTIES OF A SIMILAR T24 STEEL WELDED JOINT AFTER SERVICE
}

\begin{abstract}
The material under investigation was a welded joint made of 7CrMoVTiB10-10 (T24) steel after 36,000 hours of use at the temperature of $540^{\circ} \mathrm{C}$ and pressure of $27 \mathrm{MPa}$. The test samples for the study were taken from a membrane wall of a USC steam boiler. The research scope included: analysis of chemical composition of the original and the additional material (weld pass), investigation of the microstructure using optical microscopy and scanning electron microscopy, as well as tests of mechanical properties of the joint-hardness measurement. It was proved that the investigated joint was characterised by a regular structure, without any welding defects, which probably resulted from the application of the additional material based on the CrMo steel from the weld root side. The observation showed that the microstructure of the original material consisted of granular bainite with numerous precipitates. In the heat affected zone and in the weld, the microstructure of lath bainite (bainitic-martensitic microstructure) was observed, also with numerous precipitates. The hardness of the analysed joint was lower than the limiting value of $350 H V$.
\end{abstract}

Keywords: T24 bainitic steel, welded joint, microstructure, mechanical properties

\section{MIKROSTRUKTURA I WEAŚCIWOŚCI MECHANICZNE JEDNOIMIENNEGO ZŁACZA SPAWANEGO STALI T24 PO EKSPLOATACJI}

\begin{abstract}
Badaniu poddano jednoimienne złacze spawane stali 7CrMoVTiB10-10 (T24) po ok. 36000 godzinach eksploatacji $w$ temperaturze $540^{\circ} \mathrm{C}$ i ciśnieniu $27 \mathrm{MPa}$. Próbki do badań pobrano z wycinka ściany szczelnej kotła energetycznego na parametry nadkrytyczne. Zakres przeprowadzonych badań obejmowat: analize składu chemicznego materiału rodzimego oraz materiału dodatkowego, badania mikrostrukturalne za pomoca mikroskopii świetlnej $i$ skaningowej mikroskopii elektronowej oraz badania właściwości mechanicznych złącza-pomiar twardości. Wykazano, że badane złącze charakteryzuje się prawidtowa budowa, bez niezgodności spawalniczych, co zapewne wynika z zastosowania od strony grani materiału dodatkowego na bazie stali CrMo. Przeprowadzone obserwacje wykazały, że mikrostruktura materiału rodzimego składa się $z$ bainitu ziarnistego $z$ licznymi wydzieleniami. W strefie wptywu ciepta $i$ spoinie obserwowano mikrostrukturę bainitu listwowego (bainityczno-martenzytyczna) również z licznymi wydzieleniami. Twardość analizowanego złącza była niższa od wartości granicznej wynoszacej $350 H V$.
\end{abstract}

Stowa kluczowe: bainityczna stal T24, jednoimienne złącze spawane, mikrostruktura, właściwości mechaniczne

\section{INTRODUCTION}

Increasing the efficiency of power units resulting from the desire to reduce emissions of pollutants into the atmosphere is related to the use of appropriate construction materials, mainly steels and heat-resistant steels, which could endure super and super-critical conditions. The response to the demand of the power industry, in addition to high-chromium steels like T/P91, T/P92 and VM12, was, among others, low-alloy bainitic steel 7CrMoVTiB10-10 (T/P24). The T24 steel has been developed in Europe as a competitive product for the Japanese T23 bainitic steel. Steel T24 was created as a result of modification and optimisation of the chemical composition of the 10CrMo9-10 (T22) steel and consisted in the introduction of additives and micro-additives such as: vanadium, titanium, boron and nitrogen $[1 \div 3]$ into its composition. The introduction of vanadium and titanium micro-additives to the T24 steel results in the precipitation of MX (MC) particles. Boron micro-additive increases the hardenability of steel, and also, substituting carbon atoms, it forms $\mathrm{M}_{23}(\mathrm{C}, \mathrm{B})_{6}$ carboborides. Nitrogen, in turn, is introduced to reduce the carbon content [3, 4].

Steel T24 was to be, according to the manufacturer's data, a steel that was well weldable; with a wall thickness of less than $10 \mathrm{~mm}$, it was not to require heat treatment after welding. This steel is mainly intended for building walls of tight power units with supercritical operation parameters. The manufacturer's optimistic assumptions regarding the weldability of the T24 steel were quickly verified by industrial practice, which revealed significant problems during welding, assembly and use of this steel. These problems were mainly

Agata Merda, MSc, Eng., Prof. Grzegorz Golański, PhD, Eng. (golanski.grzegorz@wip.pcz.pl), Klaudia Klimaszewska, MSc, Eng. - Czestochowa University of Technology, Institute of Materials Engineering, Al. Armii Krajowej 19, 42-201 Częstochowa Paweł Urbańczyk, PhD, Eng. - Office of Technical Inspection Regional Branch in Katowice, Office in Dąbrowa Górnicza, ul. Przybylaka 8, 41-300 Dąbrowa Górnicza 
related to the cracking of welded joints in power units, which involved high costs of repairs of these units and financial losses caused by their stoppage $[1,5,6]$.

The main cause of the failure were transverse cracks in welded joints in tight walls, as welds connecting a flat bar with a tube, forming radiant tubes. The main mechanism causing the formation of cracks were hot cracks, and their further development occurred in the form of cold delayed cracks [1-3, 5-10]. The hot cracking of the T24 steel joints was related to its very high strength properties in the state without heat treatment as compared to the properties of the tube and flat bar. The high yield strength of the weld material prevents the relaxation of tensile stress resulting from shrinkage of the weld during its cooling, which resulted in the formation of hot cracks in the above case [8]. According to [5-10], the formation of hot cracks is also influenced by the welding speed being too high (above $0.7 \mathrm{~m} / \mathrm{min}$ ). One of the solutions reducing the risk of this type of damage, in addition to heat treatment after welding, is the use of additional material with higher plastic properties (e.g. with a chemical composition similar to the 10CrMo9-10 steel). Also, the use of hybrid welding (combination of laser welding and MAG welding) allows the production of T24 steel sheet panels without cracks [11].

The article presents the results of metallurgical studies on a 7CrMoVTiB10-10 (T24) steel welded joint after use.

\section{MATERIAL AND METHODOLOGY}

The test material was a similar welded joint made on a $38 \times 8 \mathrm{~mm}$ tube taken from a tight wall of a supercritical steam boiler. The tube material was the T24 steel. The analysed joint was used for about 36,014 hours at $540^{\circ} \mathrm{C}$ and the pressure of $26.8 \mathrm{MPa}$. The tested joint, according to the operator's data, was not subjected to heat treatment after welding. The analysis of chemical composition of the T24 steel original material was carried out using a SPECTROLAB K2 spark spectrometer, while the analysis of chemical composition of the additive material was carried out using a JOEL JSM6610 LV scanning electron microscope coupled with an Oxford Instruments X-Max EDS microanalyser.

The macroscopic examinations were carried out using a photographic camera with a CCD 1/2.5" matrix on a metallographic microsection etched with a reagent - nital.

The observation and recording of microstructure images were made using an Axiovert 25 light microscope (LM) and a JOEL JSM-6610 LV scanning electron microscope (SEM).

The measurement of the hardness of the tested T24 steel welded joint was carried out using the Vickers method according to the standard [12] with an indenter load of $10 \mathrm{~kg}(98.1 \mathrm{~N})$. The measurement of joint hardness was carried out using a Future Tech FV-700 hardness meter. The measurement was carried out from the face side and from the root side in accordance with the requirements of the standard [13].

\section{TEST RESULTS}

\subsection{ANALYSIS OF THE CHEMICAL COMPOSITION OF THE ORIGINAL MATERIAL AND ADDITIVE MATERIAL IN THE TESTED T24 STEEL JOINT}

The chemical composition of the tested original material is presented in Table 1 . The analysis of the chemical composition of the weld was carried out in three areas: in the root pass, in the filling and in the face pass of the weld. The chemical composition of the weld material is presented in Table 2.

\subsection{MACROSCOPIC TESTS OF THE T24 STEEL WELDED JOINT}

The macroscopic image of the tested welded joint is shown in Figure 1.

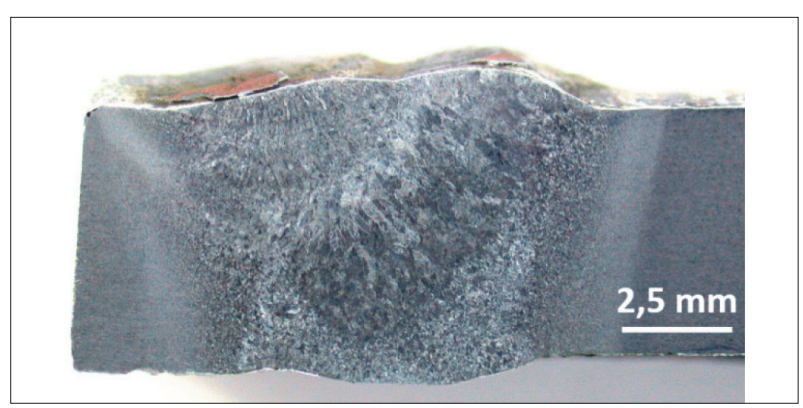

Fig. 1. Macrostructure of the T24 steel welded joint

Rys. 1. Makroskopowy obraz wycinka złącza spawanego stali T24

Table 1. Chemical composition of T24 steel, weight $\%$

Tabela 1. Skład chemiczny materiału rodzimego, \% masy

\begin{tabular}{|c|c|c|c|c|c|c|c|c|c|c|}
\hline \multicolumn{10}{|c|}{ Element concentration, weight \% } \\
\hline $\mathbf{C}$ & $\mathbf{S i}$ & $\mathbf{M n}$ & $\mathbf{F}$ & $\mathbf{S}$ & $\mathbf{C r}$ & $\mathbf{M o}$ & $\mathbf{T i}$ & $\mathbf{V}$ & $\mathbf{B}$ & $\mathbf{N}$ \\
\hline 0.07 & 0.30 & 0.43 & 0.015 & 0.004 & 2.35 & 0.97 & 0.071 & 0.22 & 0.005 & 0.017 \\
\hline
\end{tabular}

Table 2. Chemical composition of the weld, weight $\%$

Tabela 2. Skład chemiczny spoiny, \% masy

\begin{tabular}{|c|c|c|c|c|c|c|}
\hline & \multicolumn{7}{|c|}{ Element concentration, weight \% } \\
\cline { 2 - 7 } & $\mathbf{S i}$ & $\mathbf{M n}$ & $\mathbf{C r}$ & $\mathbf{M o}$ & $\mathbf{V}$ & $\mathbf{F e}$ \\
\hline Face pass & 0.17 & 0.42 & 2.84 & 1.71 & 0.37 & 94.91 \\
\hline Filling & 0.21 & 0.46 & 2.50 & 1.61 & 0.14 & 95.54 \\
\hline Root pass & 0.18 & 0.52 & 2.91 & 1.61 & - & 95.07 \\
\hline
\end{tabular}




\subsection{MICROSTRUCTURE OF THE T24 STEEL WELDED JOINT}

Sample microstructures of the tested welded joint obtained by means of light microscopy and scanning electron microscopy are shown in Figures 2-4.

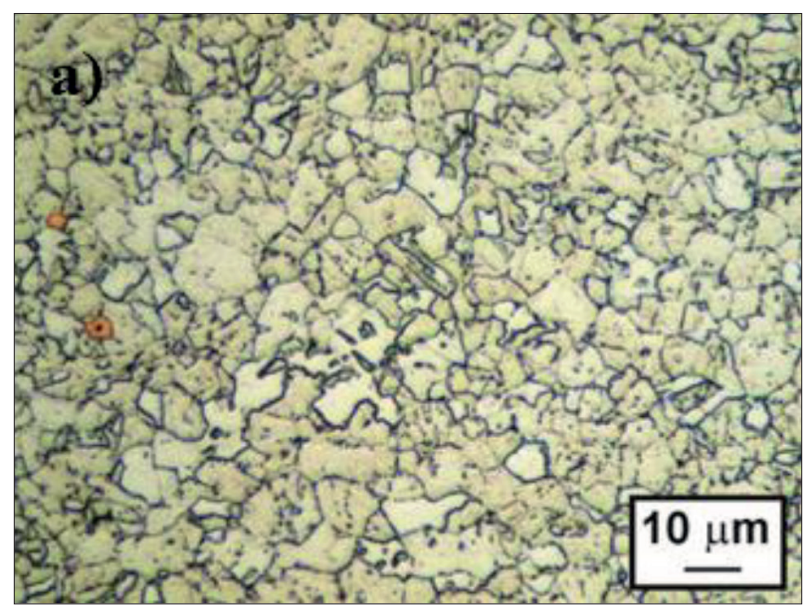

3.4. HARDNESS MEASUREMENT FOR THE T24 STEEL JOINT USING THE VICKERS METHOD

The measurement of the hardness of the tested joint was carried out in accordance with the diagram shown in Figure 5, while the obtained results are shown graphically in Figure 6.

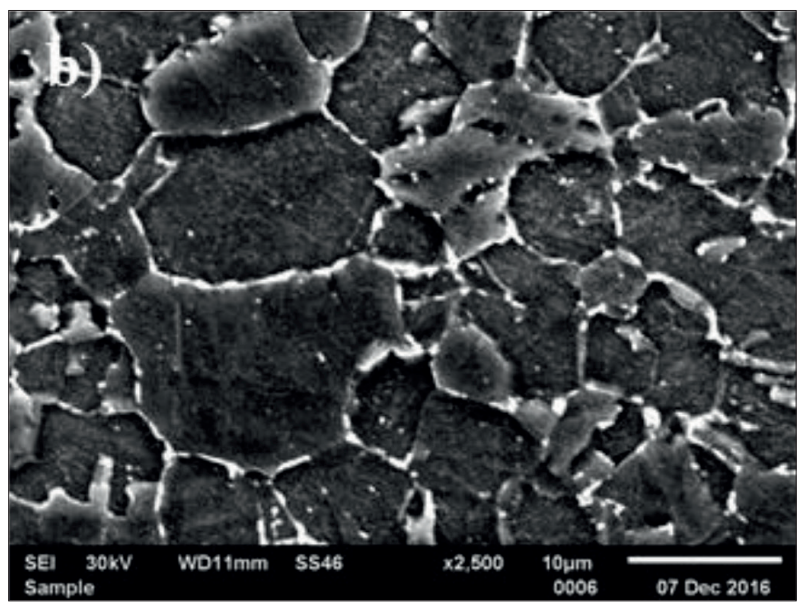

Fig. 2. Microstructure of the T24 steel: a) OM, b) SEM

Rys. 2. Mikrostruktura materiału rodzimego złącza stali T24: a) OM, b) SEM
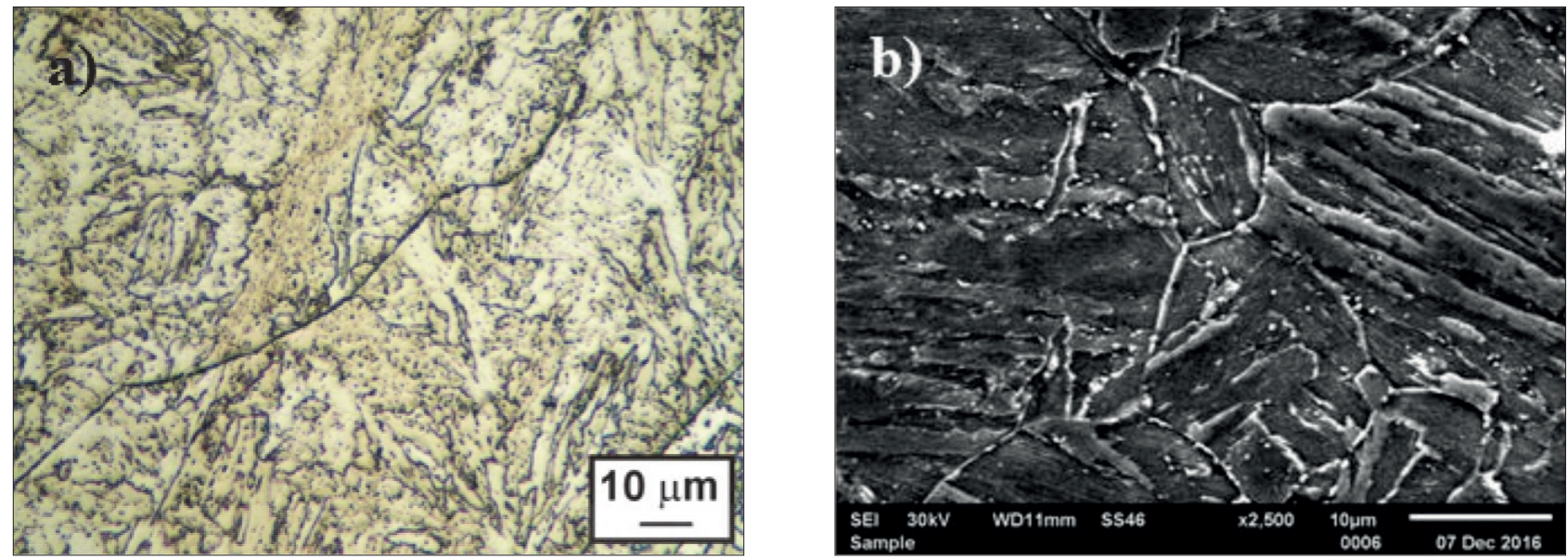

Fig. 3. Microstructure of heat affected zone (HAZ) of the T24 steel welded joint: a) OM, b) SEM

Rys. 3. Mikrostruktura strefy wpływu ciepła złącza stali T24: a) OM, b) SEM
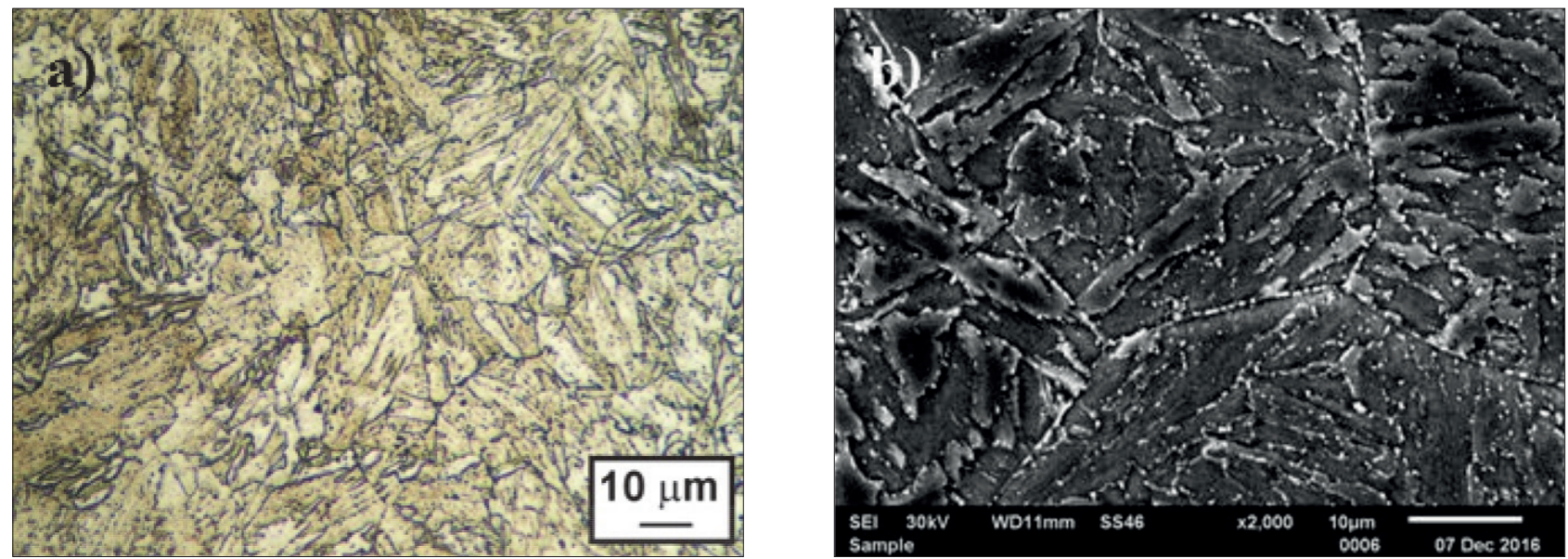

Fig. 4. Microstructure of the weld: a) OM, b) SEM

Rys. 4. Mikrostruktura spoiny: a) OM, b) SEM 


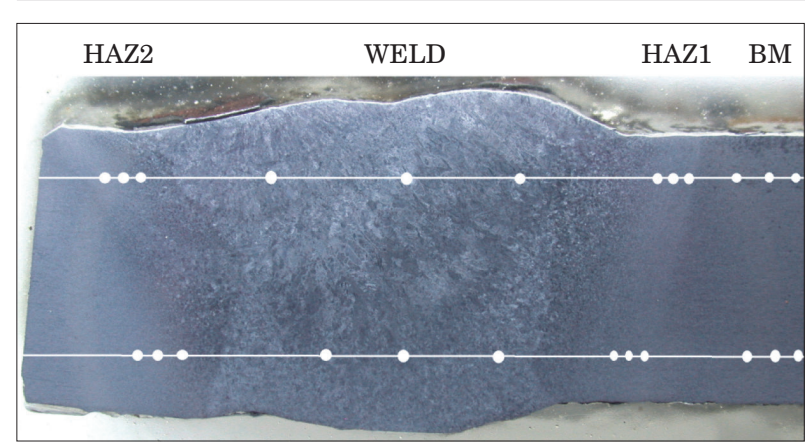

Fig. 5. Distribution of hardness points

Rys. 5. Schemat rozkładu punktów pomiarowych

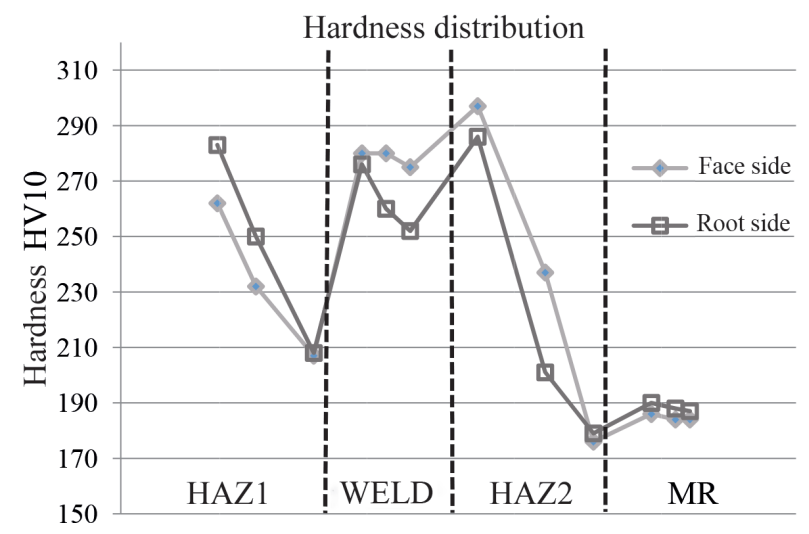

Fig. 6. Hardness distribution of the welded joint Rys. 6. Rozkład twardości w złączu spawanym

\section{ANALYSIS AND DISCUSSION OF TEST RESULTS}

The analysis of chemical composition of the original material (Table 1) showed that the tested material was the low-alloy bainitic T24 steel, with a composition corresponding to the requirements of the standard [14]. In the case of the analysis of the weld material (Tab. 2), it was shown that the additional material used in the root weld was probably a material with a chemical composition similar to that of CrMo steel, e.g. 10CrMo9-10. However, an additional $\mathrm{CrMoV}(\mathrm{Nb})$-type material for welding the T24 steel was used as a face pass and filling. The use of a welding wire with a chemical composition similar to that of CrMo steel as a root filling in the analysed welded joint was probably supposed to prevent the formation of cracks in this joint. The additional material with a chemical composition similar to CrMo steel probably has better ductility as compared to the additional material for T24 steel welding. This limits the tendency to hot cracking in T24 steel welded joints $[1,6,10,15]$. However, this material has a lower creep resistance as compared to the T24 steel $[1,10]$.

The macroscopic examination on the cross-section of the T24 steel similar welded joint showed its correct structure and did not reveal the presence of welding incompatibilities that exceed quality level " $\mathrm{B}$ " in the analysed cross-section (Fig. 1). This indicates that with a properly selected welding method, proper welding (selection of the appropriate welding parameters) and the use of additional material with high plasticity in the root pass an inconsistency-free T24 welded joint can be obtained.

The original material (OM) of the T24 steel was characterised by the microstructure of the so-called granular bainite with numerous carbides on the grain boundaries of the former austenite and the boundaries of bainite grains (Fig. 2). In the microstructure with the dominant content of granular bainite, low-angle boundaries prevail. The ratio of low- to wide-angle boundaries is an important factor affecting the mechanical properties of steel. The dominance of low-angle boundaries with a misorientation angle of less than $5^{\circ}$ in the steel microstructure ensures better creep resistance and slower degradation during use [15, 16]. Characteristic large, original titanium carbide (TiC) precipitates were observed in the OM microstructure (Fig. 2a). In the T24 steel at the initial state on grain boundaries, carbides rich in $\mathrm{M}_{23} \mathrm{C}_{6}$ chromium are observed, while inside the laths/grains, fine dispersed MX carbides/nitrides rich in vanadium precipitate [17, 18]. $\mathrm{M}_{23} \mathrm{C}_{6}$ carbides and fine dispersed vanadium-rich $\mathrm{MX}$ precipitates strengthen the precipitation mechanism of the T24 steel. A long-term use of the bainitic T24 steel leads mainly to the precipitation of molybdenum-rich $\mathrm{M}_{2} \mathrm{C}$ and $\mathrm{M}_{6} \mathrm{C}$ carbides inside grains. The type of the dominant molybdenum-rich carbide depends on the operating temperature $[18,19]$. In places, the number of precipitated particles on the borders was so numerous that they formed the so-called continuous network of precipitates. During the use of the T24 steel at an elevated temperature, processes of coagulation and spheroidisation of $\mathrm{M}_{23} \mathrm{C}_{6}$ carbides are also observed. MX precipitates as thermodynamically phases stable during long-term use practically do not increase [21, $22]$. The grain size in the native material estimated with a comparative method was 10 according to the ASTM standard scale [23]. This size corresponds to an average grain diameter of $11 \mu \mathrm{m}$.

In the heat affected zone (HAZ), the microstructure of lath bainite or bainitic and martensitic microstructure with a large number of precipitates on grain boundaries of former austenite, bainite (martensite) laths and inside bainite laths/grains were observed (Fig. 3). Within the area of HAZ of T24, two main areas were observed: I near the fusion line - coarse-grain zone and II - fine grain zone. The formation of the above areas is related to the influence of temperature in a given joint zone. Within area I, the grain size was $7(31 \mu \mathrm{m})$, while in area II $-11(7.81 \mu \mathrm{m})$. Within the HAZ area, as in $\mathrm{OM}$, the number of precipitates was so large that they formed the so-called continuous network of precipitates.

The weld was characterised by a microstructure similar to HAZ, i.e. the lath bainite microstructures (bainitic and martensitic microstructure) were visible, with numerous carbide precipitates on grain boundaries of former austenite, boundaries of bainite laths and inside bainite laths/grains. In the weld, as compared to HAZ, a coarse grain structure was observed (Fig. 4).

The examination of the mechanical properties of the analysed joint included, due to the amount of available test material, hardness measurement (Fig. 6). The distribution of hardness on the cross-section from the face and from the root was similar (Fig. 6). The measurement showed that the highest hardness was characteristic for HAZ - from the front, the hardness 
was 297 HV10, while from the side of the root, it was 286 HV10. OM was characterised by the lowest hardness - 185 HV10 from the face, and 188 HV10 from the root (Fig. 6). The obtained hardness results were lower than the value of $350 \mathrm{HV}$, which is assumed as a limit value, which allows to protect the welded joint against cold cracking.

\section{CONCLUSIONS}

The following conclusions were made on the basis of the conducted studies:
- the tested joint was of proper construction and did not have welding incompatibilities, which may indicate a suitably chosen welding method and its proper execution,

- the lack of visible cracks in the analysed joint probably results from the use of a welding wire with a composition corresponding to the CrMo steel as an additional material - a material with higher plastic properties as compared to additional material suitable for welding for the T24 steel,

- the hardness of the studied joint did not exceed the permissible maximum value of $350 \mathrm{HV}$.

\section{REFERENCES}

[1] G. Golański, J. Jasiak, J. Słania, C. Kolan. Charakterystyka bainitycznej stali 7CrMoVTiB10-10 (T24). Inżynieria Materiałowa, 2015 (4), p. 183-189.

[2] W. Bendrick, J. Gabrel, B. Hahn, B. Vandenberghe. New low alloy heat resistant ferritic steels T/P23 and T/P24 for power plant application. International Journal of Pressure Vessels and Piping, 2012, 84, p. 13-20.

[3] G. Golański, S. Stachura. Charakterystyka nowych niskostopowych stali dla energetyki. Hutnik - Wiadomości Hutnicze, 2009 (9), p. 679-683.

[4]F.B. Pickering. Historical development and microstructure of high chromium ferritic steels for high temperature applications. Microstructural development and stability in high chromium ferritic power plant steels. In: Strang A., Gooch D.J. (Ed.), The Institute of Materials, London: 1997, p. 1-29.

[5]A. Ziewiec, K. Pańcikiewicz, E. Tasak. Pękanie spoin w stali 7CrMoVTiB10-10 (T24) w czasie spawania, uruchamiania i eksploatacji bloków energetycznych. Przegląd Spawalnictwa, 2012 (5), p. 2-7.

[6] G. Golański, J. Jasak, J. Słania. Microstructure, properties and welding of T24 steel - critical review. Kovove Mater., 2014, 52, p. 1-8.

[7] K. Pańcikiewicz, S. Kwiecień, E. Tasak. Właściwości połączeń spawanych stali 7CrMoVTiB10-10 (T24) po obróbce cieplnej. Przegląd Spawalnictwa, 2012 (1), p. 15-17.

[8] A. Ziewiec, S. Parzych, E. Tasak. Skłonność do pęknięć zimnych stali bainitycznej stosowanej w podwyższonych temperaturach. Hutnik - Wiadomości Hutnicze, 2011 (12), p. 978981.

[9] E. Tasak, A. Ziewiec, K. Pańcikiewicz. Problemy materiałowe przy wytwarzaniu ścian szczelnych kotłów energetycznych na parametry nadkrytyczne. Hutnik - Wiadomości Hutnicze, 2012 (4), p. 247-253.

[10] M. Łomozik, M. Zeman, S. Fudali, J. Hajda. Przyczyny pękania złączy spawanych w ścianach szczelnych ze stali 7CrMoVTiB10-10 (T24). Energetyka XXI, 2010, p. 87-91.

[11] W. Gawrysiuk. Spawanie hybrydowe (laser + MAG) paneli ścian szczelnych kotłów energetycznych stali 7CrMoVTiB10-10. Przeglad Spawalnictwa, 2014, 86 (5), p. $43-48$.

[12] Polski Komitet Normalizacyjny. PN-EN ISO 6507-1:201805: Metale - Pomiar twardości sposobem Vickersa - Część 1: Metoda badań. 2018.
[13] Polski Komitet Normalizacyjny. PN-EN ISO 9015-1:2011: Badania niszczace złaczy spawanych metali-Badanie twardości-Część 1: Badanie twardości złączy spawanych tukowo. 2011.

[14] Polski Komitet Normalizacyjny. PN-EN 10216-2:2014-02: Rury stalowe bez szwu do zastosowań ciśnieniowych - Warunki techniczne dostawy - Część 2: Rury ze stali niestopowych $i$ stopowych $z$ określonymi właściwościami $w$ temperaturze podwyższonej. 2014.

[15] J. Dobrzański. Reason of analysis of welded joint cracking in membrane wall elements as a basis for manufacturing technology selection of the evaporator collector with new generation low-alloy bainitic steel for boilers with supercritical working parameters. Archives of Materials Science and Engineering, 2013, 64 (1), p. 5-14.

[16] A. Aghajani, Ch. Somsen, J. Pesicka, W. Bendick, B. Hahn, G. Eggeler. Microstructural evolution in T24, a modified $2(1 / 4) \mathrm{Cr}-1 \mathrm{Mo}$ steel during creep after different heat treatments. Materials Science and Engineering A, 2009, 510-511, p. 130-135.

[17]G. Golański, P. Wieczorek, K. Prusik, C. Kolan. Changes of microstructure and mechanical properties of 7CrMoVTiB 10-10 (T24) steel after long term ageing at the temperature of $580^{\circ} \mathrm{C}$. Inżynieria Materiałowa, 2011 (1), pp. 50-54.

[18] A. Kroupa, A. Vyrostkova, M. Svoboda, J. Janovec. Carbide reactions and phase equilibria in low-alloy Cr-Mo-V steels tempered at 773-993 K. Part II: theoretical calculations. Acta Materialia, 1998, 46, p. 39-49.

[19] A. Zieliński, G. Golański, M. Sroka. Influence of long-term ageing on the microstructure and mechanical properties of T24 steel. Materials Science and Engineering, 2017, A 682, p. 664-672.

[20] F. Abe. Precipitate design for creep strengthening of 9\% Cr tempered martensitic steel for ultra-supercritical power plants. Sci. Technol. Adv. Mater., 2008 (9), p. 1-15.

[21] J. Hald, Microstructure and long-term creep properties of 9-12\% Cr steels. International Journal of Pressure Vessels and Piping, 2008, 85, p. 30-37.

[22] Polski Komitet Normalizacyjny. PN-EN ISO 643:2013-06: Stal - Mikrograficzne określanie wielkości ziarna. 2013. 